\title{
AC 2010-1964: TEACHERS AS SCIENTISTS: A QUALITATIVE STUDY OF OUTCOMES FOR AN RET PROGRAM
}

\section{Lisa Benson, Clemson University}

Lisa C. Benson is an Assistant Professor in the Department of Engineering and Science Education at Clemson University, with a joint appointment in the Department of Bioengineering. Dr.

Benson teaches first year engineering, undergraduate research methods, and graduate engineering education courses. Her research interests include student-centered active learning in undergraduate engineering, assessment of motivation, and how motivation affects student learning. She is also involved in projects that utilize Tablet PCs to enhance student learning. Her education includes a B.S. in Bioengineering from the University of Vermont, and M.S. and Ph.D. degrees in Bioengineering from Clemson University.

\section{Emily Medders, Southern Wesleyan University}

Cheryl A. P. Cass is a Ph.D. candidate and graduate research assistant in the Department of Bioengineering at Clemson University and is working towards a graduate certificate in the Department of Engineering and Science Education at Clemson. She also serves as lab manager in the Institute for Biological Interfaces of Engineering at Clemson. Cheryl was active as a research mentor in several federally funded summer research programs and has also been involved in many tutoring and outreach efforts. Her current research interests include discerning student misconceptions of science and engineering content. Cheryl's education includes B.S. degrees in Biological and Agricultural Engineering and Biomedical Engineering from North Carolina State University and an M.S. degree in Bioengineering from Clemson University.

\section{Cheryl Cass, Clemson University}

Emily G. Medders is a mathematics education major at Southern Wesleyan University, and an undergraduate research assistant in the Department of Engineering and Science Education at Clemson University. 


\title{
Teachers as Scientists: A Qualitative Study of Outcomes for an RET Program
}

\begin{abstract}
This study examined the development of teachers as scientists for participants in a NSF Research Experiences for Teachers (RET) program in terms of their technical and scientific expertise and an understanding of the nature of science. Our RET program is a six week summer program in which secondary science and math teachers are immersed in research environments related to polymers and polymer processing. Using Bloom's revised taxonomy of cognitive development, we identified the teachers' levels of cognitive operation. Verbs describing teachers' actions in their research environment in terms of science and the process of scientific inquiry were categorized into different levels of cognitive development (understanding, applying, analyzing, etc). Elements from studies on adult learning and learning in general were combined to form a four-level scale to assess teachers' independence as researchers, their focus, their relationship with their mentors and graduate assistants, and the structure of their environment. Hierarchies developed from these theoretical frameworks allowed tracking of changes over time for the attributes of interest. We also examined the roles that mentors played in the process and the level of independence achieved in scientific practice by the teachers.

Participants included ten teachers with varying levels of education and experience. Data included weekly journal entries written during the program and exit interviews conducted at the conclusion of the program. Data were coded with respect to the two hierarchies, and then evidence pertaining to mentors and independent practice were extracted and examined. Increases in functionality as researchers, level of cognition of scientific topics, and/or level of independence were observed for all teachers who completed the program. Differences were observed in levels achieved and rates of development within each construct, due to teachers' individual characteristics and relationships with mentors. Six of nine teachers completing the program reached their highest level of functionality by Week 3, indicating that a six week program is an appropriate period for teachers to develop, and have time to function, as scientists. Mentors had a clear influence on the development of teachers' independent scientific practice. Accessibility of mentors, but not necessarily physical presence, was key to a successful experience. Encouragement and openness to new ideas also were key factors in positive mentor/mentee relationships.
\end{abstract}

\section{Introduction}

This study comprises an analysis of data collected from participants in the 2008 Research Experiences for Teachers (RET) program at the Center for Advanced Engineering Fibers and Films (Clemson University and Clark Atlanta University). This six-week internship program placed secondary science and mathematics teachers in authentic research environments, with the goal of enhancing science, technology, engineering and mathematics (STEM) education by 
reinforcing technical content and illustrating the interconnections between disciplines such as math and chemistry. We seek to answer the following research questions:

- How do teachers develop as scientific researchers when immersed in a research project?

- How well do they understand the research process after participation in this experience?

- What role do their mentors serve in their development as scientific researchers?

Development of technical and scientific expertise and an understanding of the nature of science are desired professional development experiences for teachers ${ }^{1}$ and for emerging scientists ${ }^{2}$. We hypothesized that our data would elucidate changes in the teachers' understanding of technical topics and methodologies, and independence with scientific practice. We chose therefore to examine the data collected from the point of view of cognitive development and functionality.

\section{Theoretical Framework}

Using Bloom's revised taxonomy of cognitive development, we identified the teachers' levels of cognitive operation based on how these verbs described actions by the teachers in their research environment in terms of science and the process of scientific inquiry ${ }^{3}$. Bloom's revised taxonomy consists of six levels: remembering, understanding, applying, analyzing, evaluating, and creating. We created a seventh level below "remembering" for instances when participants were unable to grasp concepts (e.g. "That lab work seems unclear. I have no idea at this point as to what I am going to be doing." Bob, Wk 1). Each level requires mastery of all previous levels, with the understanding that one cannot apply a procedure in the lab without first remembering what the procedure is and understanding how to do it. Thus the presence of lower level cognitive stages late in the program does not have negative connotations if higher levels of cognition are also present.

We also sought to develop a measure of teachers' functionality as scientific researchers. Elements from studies on adult learning and learning in general ${ }^{4-7}$ were combined to form a fourlevel scale to assess teachers' independence as researchers, their focus, their relationship with their mentors and graduate assistants, and the structure of their environment. These sources present sequences of functional stages, organized in a hierarchical arrangement from less to more complex. These theoretical frameworks were the basis for a scale of functionality developed for coding data.

\section{Methods}

Ten teachers (six females; mean age $=41.8$ years \pm 11.84 ; seven Caucasians, two African Americans, and one Asian American) taught in STEM subject areas including Geometry, Algebra, Physical Science, Biology, Calculus, and Probability and Statistics, in grades 8 - 12. They had varying amounts of education, with one only having a BS, two having completed some work towards their masters, four having completed a master's degree, two having completed some work towards their doctorate, and one with a $\mathrm{Ph}$. D. Eight participants were placed in engineering labs, and one each in math and chemistry labs.

Our data included weekly journal entries and exit interviews (Table 1). Journal entries were contemporaneous observations during the course of the program, in contrast to Exit interviews, conducted by the RET program director, which were retrospective reflections at the end of the program. All data were self reported, which may be skewed by false reports of what was actually taking place; however this limitation is offset by having two sources of data. 
The data were coded using a qualitative analysis program (NVivo 7, QSR International, Melbourne, Australia). The coding structure consisted of two hierarchies, Bloom's revised taxonomy of cognitive development and a functionality scale (Table 2). Coding of journal entries and interviews was conducted by a team member (pre-service teacher) with no affiliation to the RET program and no prior experience as a scientist or engineer, and thus has no content specificity. Since the theoretical frameworks doubled as the coding structure, the coder constantly referenced both Bloom's revised taxonomy for cognitive development and the scale of functionality, thus providing validity to the coding procedure. After all data had been coded, codes were reviewed, and recoded if necessary, within each category/functionality level to check for consistency. Each case (teacher) and the data set as a whole were analyzed in two ways: functionality versus time (weeks in the program), and cognitive development versus time.

Table 1. Weekly journal questions and general topics addressed in exit interviews.

\begin{tabular}{|l|l|l|}
\hline Week 1 & Weeks 2-5 & Exit Interview Categories \\
\hline - What expectations do & $\bullet$ What tasks were you involved in this week? & $\bullet$ Motivation/expectations \\
$\begin{array}{l}\text { you have for your } \\
\text { participation in the RET }\end{array}$ & - What was your biggest accomplishment this week? & $\bullet$ Research training \& \\
program? & - What was your biggest frustration or challenge? & mentoring \\
- Why did you want to & - What went wrong? What went well? & $\bullet$ Self-efficacy for \\
participate in this RET & - What have you been doing related to your & Scientific research \\
program? & engineering teaching module? & Self-efficacy for teaching \\
engineering
\end{tabular}

Table 2. Coding structure to measure RET interns' functionality as scientific researchers.

\begin{tabular}{|c|c|c|c|c|}
\hline Constructs & 1. Low & 2. Low-Middle & 3. High-Middle & 4. High \\
\hline $\begin{array}{l}\text { - Internal vs. } \\
\text { external standards } \\
\text { - Focus } \\
\text { - Structure } \\
\text { - Relationship with } \\
\text { mentors } \\
\text { - The ability to } \\
\text { create new } \\
\text { concepts } \\
\text { - Dependence / } \\
\text { independence } \\
\text { - Program } \\
\text { expectations }\end{array}$ & $\begin{array}{l}\text { - Expectations as } \\
\text { a standard } \\
\text { - Focus on } \\
\text { personal need } \\
\text { - High Structure } \\
\text { - Selfish } \\
\text { relationship } \\
\text { with mentors }\end{array}$ & $\begin{array}{l}\text { - External standards } \\
\text { - Focus on concrete } \\
\text { need } \\
\text { - Mid-high structure } \\
\text { - Subordinate } \\
\text { relationship with } \\
\text { mentors } \\
\text { - Cannot develop } \\
\text { new concepts } \\
\text { - Dependent } \\
\text { - Realize the } \\
\text { inadequacies of } \\
\text { their expectations }\end{array}$ & $\begin{array}{l}\text { - Internal / External } \\
\text { standards } \\
\text { - Focus on Duty } \\
\text { - Moderate structure } \\
\text { - Facilitator } \\
\text { relationship with } \\
\text { mentors } \\
\text { - Can create new } \\
\text { concepts with } \\
\text { External help } \\
\text { - Dependent/ } \\
\text { Independent }\end{array}$ & $\begin{array}{l}\text { - Internal } \\
\text { standards } \\
\text { - Focus on } \\
\text { autonomous will } \\
\text { - Low structure } \\
\text { - Peer relationship } \\
\text { with mentors } \\
\text { - Can develop new } \\
\text { concepts } \\
\text { - Independent }\end{array}$ \\
\hline
\end{tabular}

Role(s) of mentors were identified within coded data by tallying how many times the teacher mentioned either graduate students or faculty advisors. Each of the comments containing statements about these mentors was rated as either positive or negative, taking into account the overall goal of the RET program to promote independent thinking and research. Descriptions by the teachers of their practice in the lab were examined to see how often they used "I" and "we" as measure of their independence in practice. 


\section{Results}

The methods were able to distinguish teachers who entered the program at a high level of functionality (Table 3a) and cognition (Table 3b) versus those who progressed to those levels, as well as how quickly they progressed. Differences were observed between teachers in their progress, due in part to their background and experience. For example, May, who has a B.S. degree in Chemical Engineering, was running tests and evaluating results early on:

"I got back good results and was able to learn many different aspects of the research including running instruments and methods of testing." (May, Wk 2, "Evaluating”)

May had four years teaching experience, and those who had less than 10 years of STEM teaching experience tended to develop to a higher level as scientists. They showed openness to new experiences:

"My research goals have evolved as I learned how to make nanoparticles then I learned how to put them in, or tried to put them in a DPP C layer. So my research evolved as I gained experience over the summer." (Joy, Exit Interview, "Applying”, Functional Level 4)

Table 3. All cases (except 1 who dropped out), normalized to $\%$ of responses, shaded by value.

3a. Functionality vs. time

\begin{tabular}{|l|c|c|c|c|c|c|}
\cline { 2 - 7 } \multicolumn{1}{c|}{} & Wk 1 & Wk 2 & Wk 3 & Wk 4 & Wk 5 & Exit Interviews \\
\hline Low & $100 \%$ & $56 \%$ & $22 \%$ & $17 \%$ & $0 \%$ & $100 \%$ \\
\hline Low-Middle & $0 \%$ & $56 \%$ & $56 \%$ & $33 \%$ & $0 \%$ & $89 \%$ \\
\hline High-Middle & $0 \%$ & $67 \%$ & $33 \%$ & $33 \%$ & $29 \%$ & $89 \%$ \\
\hline High & $0 \%$ & $33 \%$ & $56 \%$ & $50 \%$ & $57 \%$ & $89 \%$ \\
\hline
\end{tabular}

3b. Categorization within Bloom's Taxonomy vs. time

\begin{tabular}{|l|c|c|c|c|c|c|}
\cline { 2 - 7 } \multicolumn{1}{c|}{} & Wk 1 & Wk 2 & Wk 3 & Wk 4 & Wk 5 & Exit Interviews \\
\hline None of the above & $22 \%$ & $22 \%$ & $0 \%$ & $17 \%$ & $0 \%$ & $22 \%$ \\
\hline Remembering & $0 \%$ & $33 \%$ & $0 \%$ & $17 \%$ & $0 \%$ & $0 \%$ \\
\hline Understanding & $0 \%$ & $56 \%$ & $56 \%$ & $67 \%$ & $43 \%$ & $100 \%$ \\
\hline Applying & $0 \%$ & $78 \%$ & $78 \%$ & $67 \%$ & $57 \%$ & $100 \%$ \\
\hline Analyzing & $0 \%$ & $33 \%$ & $22 \%$ & $50 \%$ & $14 \%$ & $89 \%$ \\
\hline Evaluating & $0 \%$ & $33 \%$ & $33 \%$ & $17 \%$ & $43 \%$ & $44 \%$ \\
\hline Creating & $0 \%$ & $0 \%$ & $0 \%$ & $0 \%$ & $0 \%$ & $22 \%$ \\
\hline
\end{tabular}

Further analysis of coded data supported and explained coding results. For example, while Kat reached high levels of cognition and functionality, she clearly had not achieved independence, as shown in the following quote in which she uses "we," not "I," when describing lab activities:

"We were doing rheology testing. The data did not look good. We brainstormed together to figure out what was wrong. We concluded the volume we used was the problem. We are going to try it again with a different volume." (Kat, Wk 5, "Evaluating")

Some participants made marked progressions from solidly in the lower functionality at the start to mid-high and high by the exit interviews. However, in some cases, functionality was categorized somewhat lower because of a focus on personal need - a reflection of "what I got out of this" and not reflective of the participant's ability to function in a research lab. 
"I really wanted the research experience. I'd never been in a real research lab and I'd just been in the four walls of my classroom for the past decade or so and I really wanted to ... branch out and get some more experience. I know it would look good on a resume honestly. Because I'm not looking to stay in high school education setting....I've been teaching 12 years and.... you tend to get burned out after awhile. So this was kind of a nice little change of pace and a nice little, like a little vacation from reality... something that I had never experienced before." (Ann, Exit Interview, Functional Level 1)

Similarly focused on personal needs, Bob was solidly in the low and low-middle functionality throughout his experience, and actually quit after only two weeks of the program. In contrast to Ann, Bob was entirely focused on the teaching module rather than allowing himself to ever be immersed in the research side of the program. In his exit interview, he reflected on this.

"I think [my mentor] wanted me to meet the goals of the program and do the research properly and I was trying to shoehorn that into what I could do for a low level CP level and Honors level class and really should have been focused more on what just research was. Instead of trying to figure out okay, how am I going to do that and what am I going to use it with and that sort of thing, and that was one of my problems that I was constantly trying to think about, how to do it in the classroom." (Bob, Exit Interview, Functional Level 1)

Mentors were referenced by teachers most often in Week 2 (15 times/10 teachers). Only Bob noted his mentor in Week 1, and he dropped from the program in Week 3.

"My meeting with my professor did not go very well. I think he now understands the limited knowledge I bring and the ability range of my students...I have no idea at this point as to what I am going to be doing. Communication may be a problem." (Bob, Wk 1, Functional Level 1)

Only Kat noted her mentor in Week 5, consistent with earlier noted dependence on her mentor. She noted mentors 6 times in the exit interview, all considered "negative," since she discussed working side by side, wanting to simply follow a protocol, and her mentor's lack of encouragement of new ideas. It appears the mentor was overly accessible and did not challenge Kat to work independently. Conversely, Joy did not note her mentor in her journals, and only discussed him briefly when prompted in her Exit Interview. He was "very accessible," communicating by email when he was not physically present:

"At first I was struggling with that, but I think in the end it made me a better researcher because I had to find things on my own and resolve issues on my own..."

Sam noted mentors most frequently in the Exit Interview, and most comments were related to encouragement and acceptance of new ideas (82\%). Along with his education, this likely contributed to him having one of the highest "independence" ratings. 
Table 4. Summary of teacher profiles, cognitive and functionality levels, and indications of independent scientific practice based on the use of "I" or "we" in discussions of research practices ranked in decreasing order of development as scientists. Teacher profile information includes age, gender, highest degree obtained, number of years teaching a STEM discipline, and what they are currently teaching. Functionality levels $1-4$ refer to "Low" to "High"

\begin{tabular}{|c|c|c|c|c|}
\hline Case & Profile & Cognitive Progression & Functional Progression & Independent Practice \\
\hline Sam & $\begin{array}{l}57 \text { y.o. M; Ph.D.; } \\
6.5 \text { yrs. teaching; } \\
\text { Pre-Algebra, } \\
\text { Algebra, Geometry }\end{array}$ & $\begin{array}{l}\text { Started relatively high } \\
\text { (analyze), moved to } \\
\text { highest level at Exit } \\
\text { Interview }\end{array}$ & $\begin{array}{l}\text { Started at } 1 \text {; strong } \\
\text { evidence of Level } 4 \text { at } \\
\text { Exit Interview }\end{array}$ & $\begin{array}{l}\text { "I" referenced consistently } \\
\text { throughout }\end{array}$ \\
\hline Joy & $\begin{array}{l}27 \text { y.o. F; M.Ed.; } 4 \\
\text { yrs. teaching; } \\
\text { Science }\end{array}$ & $\begin{array}{l}\text { Started relatively high } \\
\text { (analyze), maintained } \\
\text { consistent "applying" } \\
\text { level throughout }\end{array}$ & $\begin{array}{l}\text { Jumped from } 1 \text { to } 4 \\
\text { quickly and maintained } \\
\text { high functionality } \\
\text { throughout }\end{array}$ & $\begin{array}{l}\text { "I" referenced consistently } \\
\text { throughout }\end{array}$ \\
\hline Jen & $\begin{array}{l}34 \text { y.o. F; B.S.; } 11 \\
\text { yrs. teaching; } \\
\text { Physical Science }\end{array}$ & $\begin{array}{l}\text { Started at "applying" and } \\
\text { maintained, with some } \\
\text { signs of "evaluating" } \\
\text { throughout }\end{array}$ & $\begin{array}{l}\text { Progressed from } 1 \text { to } 4 \\
\text { by Wk } 3 \text { and maintained } \\
\text { high functionality } \\
\text { throughout }\end{array}$ & $\begin{array}{l}\text { "I" referenced in lower } \\
\text { cognitive and functionality } \\
\text { levels, but less in higher } \\
\text { levels }\end{array}$ \\
\hline Joe & $\begin{array}{l}31 \text { y.o. M; B.S.; } 10 \\
\text { yrs. teaching; } \\
\text { Geometry }\end{array}$ & $\begin{array}{l}\text { Steady progress from low } \\
\text { to high over } 5 \text { weeks }\end{array}$ & $\begin{array}{l}\text { Steady progress from } 1 \\
\text { to } 3 \text { over } 4 \text { weeks, with } \\
\text { some mention of high } \\
\text { functionality at Exit } \\
\text { Interview }\end{array}$ & $\begin{array}{l}\text { "I" referenced consistently } \\
\text { throughout }\end{array}$ \\
\hline May & $\begin{array}{l}31 \text { y.o. F; M.A.T.; } 4 \\
\text { yrs. teaching; } \\
\text { Algebra } 1\end{array}$ & $\begin{array}{l}\text { Started at "applying" and } \\
\text { remained there } \\
\text { throughout; showed some } \\
\text { signs of "evaluating" at } \\
\text { Exit Interview }\end{array}$ & $\begin{array}{l}\text { Steady progress from } 1 \\
\text { to } 4 \text { by Wk } 3 \text {, ended at } \\
\text { highest level }\end{array}$ & $\begin{array}{l}\text { "I" referenced consistently } \\
\text { throughout cognitive levels } \\
\text { and in lower functionality } \\
\text { levels, but less in higher } \\
\text { functionality levels }\end{array}$ \\
\hline Ann & $\begin{array}{l}32 \text { y.o. F; M.Ed.; } 11 \\
\text { yrs. teaching; AP } \\
\text { Calculus, Prob \& } \\
\text { Stats }\end{array}$ & $\begin{array}{l}\text { Started at "applying" and } \\
\text { maintained, with some } \\
\text { signs of "evaluating" at } \\
\text { Exit Interview }\end{array}$ & $\begin{array}{l}\text { Progressed from } 1 \text { to } 4 \\
\text { by Wk } 3 \text { and maintained } \\
\text { high functionality } \\
\text { throughout }\end{array}$ & $\begin{array}{l}\text { "I" referenced consistently } \\
\text { throughout functionality } \\
\text { levels and in lower } \\
\text { cognitive levels, but not in } \\
\text { higher cognitive levels }\end{array}$ \\
\hline Jim & $\begin{array}{l}46 \text { y.o. M; M.Ed.; } \\
11 \text { yrs. teaching; } \\
\text { Physical Science }\end{array}$ & $\begin{array}{l}\text { Started at lower levels, } \\
\text { quickly progressed by Wk } \\
3 \text { (missing journal data } \\
\text { Wks } 4 \text { - 5); ended at } \\
\text { "analyzing" at Exit } \\
\text { Interview }\end{array}$ & $\begin{array}{l}\text { Started at } 1 \text {, jumped to } 3 \\
-4 \text { by } \mathrm{Wk} 2 \text {, remained } \\
\text { throughout }\end{array}$ & $\begin{array}{l}\text { "I" referenced in lower } \\
\text { cognitive and functionality } \\
\text { levels, but not in higher } \\
\text { levels }\end{array}$ \\
\hline Sue & $\begin{array}{l}52 \text { y.o. F; M.Ed.; } 14 \\
\text { yrs. teaching; } \\
\text { Biology, Physical } \\
\text { Science }\end{array}$ & $\begin{array}{l}\text { Started at "applying" and } \\
\text { remained there throughout }\end{array}$ & $\begin{array}{l}\text { Started at } 2 \text {, showed } \\
\text { some progress towards } 3, \\
\text { but ended mainly at } 2\end{array}$ & $\begin{array}{l}\text { "I" referenced consistently } \\
\text { throughout cognitive levels } \\
\text { and in lower functionality } \\
\text { levels, but not in higher } \\
\text { functionality levels }\end{array}$ \\
\hline Kat & $\begin{array}{l}55 \text { y.o. F; B.S.; } 21 \\
\text { yrs. teaching; } \\
\text { Algebra } 1 \& 2\end{array}$ & $\begin{array}{l}\text { Steady progress from low } \\
\text { to high by Wk } 3 \text {; mainly } \\
\text { "applying" with some } \\
\text { indication of higher levels }\end{array}$ & $\begin{array}{l}\text { Steady progress from } 1 \\
\text { to } 4 \text { by Wk } 5 \text {, but no } \\
\text { indication of higher } \\
\text { levels at Exit Interview }\end{array}$ & $\begin{array}{l}\text { "I" referenced in lower } \\
\text { cognitive and functionality } \\
\text { levels, but not in higher } \\
\text { levels }\end{array}$ \\
\hline Bob & $\begin{array}{l}53 \text { y.o. M; M.Ed.; } \\
31 \text { yrs. Teaching; } \\
\text { Physical Science }\end{array}$ & $\begin{array}{l}\text { Started at lowest level and } \\
\text { did not move beyond } \\
\text { "understanding" }\end{array}$ & $\begin{array}{l}\text { Started at } 1, \text { little } \\
\text { progress towards } 2\end{array}$ & $\begin{array}{l}\text { No evidence of } \\
\text { independence; "I" used } \\
\text { only in terms of his needs }\end{array}$ \\
\hline
\end{tabular}




\section{Discussion and Conclusions}

The coding methods were validated by the fact that a structure was imposed on the coding process, and it was based on well-accepted theories on adult learners. One rater completed all the coding, which can be seen as problematic. However, this is overcome by the fact that there were multiple data sources, and results were triangulated from these sources. The coder was a relatively objective team member, as she had no experience with the RET program, and no prior experience as a scientist or engineer, and thus has no content specificity. She has limited experience in education research, and is herself a pre-service teacher. The coder conducted periodic, iterative self-checks in which she recoded previously coded journal entries and interviews and compared the two results to check her own consistency. The data were recoded as necessary from the beginning if discrepancies were found.

The data showed that all teachers (except Bob) progressed in cognition and/or functionality. Bob never considered developing as a scientist, and focused on his need to develop teaching materials. While progress was made by all other teachers, the examination of their descriptions of their practices revealed whether or not they were actually functioning independently. Six of nine teachers reached their highest level of functionality by Week 3, indicating that a six week program is an appropriate period for teachers to develop, and have time to function, as scientists.

Mentors impact on teachers varied widely from case to case. It is unclear how they affected the cognitive and functionality levels that teachers achieved, but they had an obvious effect on their independent practice (or lack thereof). Accessibility of mentors, but not necessarily physical presence, was key to a successful experience. Encouragement and openness to new ideas also were key factors in positive mentor/mentee relationships. Some teachers did not mention their practice, or their mentors, or show progress in the later weeks of the program, and in many cases, this was due to the nature of the project itself. Also, since teachers were required to develop teaching materials as an outcome of the program, those tended to be their focus in the later weeks. However, their development as scientists allowed them to attend to this task, as they brought new understanding of science and research to their teaching. This is a fundamental goal of the NSF RET program itself. While mentors play an important role in teachers' development as scientists, so does the incoming education and experience of the teacher, and the scope and nature of their project. This is an area for future research.

The methodology used in this study has value in examining the multi-faceted nature of teachers' development as scientists. The construct of focus (personal needs, duty, etc.) within the functionality scale allowed us to incorporate aspects of underlying motivations behind teachers' participation, as well as other key factors to becoming scientists. Future work includes examination of journal entries and exit interviews from two other RET programs to expand the number of participants and provide a broader perspective on their experiences.

\section{Bibliography}

1. Effective STEM Professional Development: A Biomedical Engineering RET Site Project. Klein, Stacy S. 3, s.1. : TEMPUS Publications, 2009, International Journal of Engineering Education, Vol. 25, pp. 523-533. 
2. Becoming a Scientist: the Role of Undergraduate Research in Students' Cognitive, Personal, and Professional Development. Hunter, Anne-Barrie, Laursen, Sandra L. and Seymour, Elaine. 1, s.l. : Wiley Periodicals, Inc., January 2007, Science Education, Vol. 91, pp. 36-74.

3. DeMatteo, S. Bloom's Revised Taxonomy. Teaching with the Internet. [Online] May 6, 2008. [Cited: July 17, 2009.] http://twi.classroom.com/workshops/hisd_conf/materials/kay/2.\%20Bloom\%27s_Revised_Taxonomy.pdf.

4. Adult Learning Theories: Impacting Professional Development Programs. Trotter, Yvonne D. 2, Winter 2006, The Delta Kappa Gamma Bulletin, Vol. 72, pp. 8-13.

5. Person-Environment Interaction: A Challenge found Wanting Before It Was Tried. Hunt, David E. 2, s.1. :

American Educational Research Association, Spring 1975, Review of Educational Research, Vol. 45, pp. 209-230.

6. Bullough, Robert V., Knowles, J. Gary and Crow, Nedra A. Emerging as a Teacher. London : Routledge, 1992.

7. Mezirow, Jack. Learning as Transformation: Critical Perspectives on a Theory in Progress. San Francisco : Jossey-Bass, 2000. 